\title{
PELATIHAN ONLINE PENGGUNAAN GEOMETRY TOOLBOX UNTUK MENDUKUNG PEMBELAJARAN JARAK JAUH PADA MASA PANDEMI
}

\author{
Febrian $^{1}$, Puji Astuti ${ }^{2}$, Rindi Antika ${ }^{3}$ \\ ${ }^{1}$ Universitas Maritim Raja Ali Haji.Email: febrian@umrah.ac.id \\ 2Universitas Maritim Raja Ali Haji. Email: pujiastuti@umrah.ac.id \\ 3Universitas Maritim Raja Ali Haji. Email: rindiantika@umrah.ac.id
}

\begin{abstract}
Regarding the demands of the 4.0 industrial revolution where every math educator must be able to adapt to technological developments and respond quickly to the COVID-19 pandemic, teachers should improve his capacity to use technology. The results of the analysis through partner exploration with a number of teachers who are members of the Mathematics Subject Teacher Conference (MGMP) for the high school mathematics of Bintan Regency found that there is still limited knowledge about technology so that the need for training. Through Community Service (PKM) activities, online training on Geometry Toolbox is carried out, it's considered to have great potential to support distance learning. Through these activities, a learning video is produced which can be used as a distance learning resource. Four aspects of success of this activity are general assessment, relevance and significance of activities, usefulness, and aspects of increasing the knowledge, understanding and skills of participants. The data obtained by distributing questionnaire using the Google Form platform and questions and answers during activity sessions. The results of this activity show that the online Geometry Toolbox training is going very well where participants have increased knowledge, an understanding of technology integration in mathematics learning and are skilled at using the Geometry Toolbox software in packaging learning. Thus training activities have provided opportunities for teachers to be able to carry out distance learning during the COVID-19 pandemic in 2020.
\end{abstract}

Keywords: distance learning, Geometry Toolbox, online training

\begin{abstract}
ABSTRAK
Terkait tuntutan revolusi industri 4.0 dimana setiap pendidik matematika harus mampu menyesuaikan diri dengan perkembangan teknologi serta secara sigap merespon situasi pandemi COVID-19, maka guru harus meningkatkan kapasitas dirinya dalam menggunakan teknologi. Melalui penjajakan mitra terhadap sejumlah guru yang tergabung dalam Musyawarah Guru Mata Pelajaran (MGMP) Matematika tingkat SMA Kabupaten Bintan diperoleh informasi bahwa masih ada kelemahan penguasaan teknologi sehingga perlu diadakan pelatihan. Melalui kegiatan pengabdian kepada masyarakat berupa pelatihan online Geometry Toolbox dirasa memiliki potensi besar untuk mendukung pembelajaran jarak jauh. Melalui kegiatan tersebut dihasilkan video pembelajaran yang dapat dijadikan sumber belajar jarak jauh. Empat aspek penentu keberhasilan kegiatan ini adalah penilaian secara umum, relevansi dan signifkansi kegiatan, kebermanfaatan, serta aspek peningkatan pengetahuan, pemahaman dan keterampilan peserta. Data diperoleh dengan penyebaran angket menggunakan platform Google Form serta tanya jawab selama sesi kegiatan. Hasil kegiatan ini menunjukkan bahwa pelatihan online Geometry Toolbox berjalan dengan sangat baik dimana peserta memiliki peningkatan pemahaman mengenai integrasi teknologi dalam pembelajaran matematika serta terampil menggunakan software Geometry Toolbox. Dengan demikian kegiatan pelatihan ini telah mendukung pembelajaran jarakjauh pada masa pandemi 2020.
\end{abstract}

Kata Kunci: pembelajaran jarak jauh, Geometry Toolbox, pelatihan online 


\section{PENDAHULUAN}

Guru merupakan tenaga profesional yang tugasnya diatur dalam Undang-undang Nomor 14 tahun 2005 untuk melaksanakan sistem pendidikan nasional dan mewujudkan tujuan pendidikan nasional. Dengan kata lain, guru memiliki peran yang sangat besar sebagai eksekutor agar berhasilnya dunia pendidikan. Oleh sebab itu, peningkatan profesionalisme guru merupakan yang sangat penting. Sesuai dengan perannya dalam mempersiapkan sumber daya manusia menghadapi perkembangan teknologi di era revolusi industri 4.0, guru harus meningkatkan profesionalismenya seiring dengan perkembangan tersebut, yaitu meningkatkan kompetensi di bidang penguasaan teknologi infomasi dan komunikasi (TIK) seperti pendapat Astuti \& Febrian (2019) yang menjelaskan bahwa guru dalam bidang pembelajarannya harus mampu beradaptasi bahkan harus dapat memanfaatkan perkembangan dan kemajuan teknologi. Kementerian Pendidikan dan Kebudayaan (Kemendikbud) telah meluncurkan program Digitalisasi Sekolah sebagai upaya pemerintah meningkatkan kapasitas guru dalam menguasai TIK di era 4.0 (Kemdikbud, 2019; Kominfo, 2019).

Selain sebagai tuntutan perkembangan zaman, pemanfaatan teknologi merupakan tantangan sekaligus peluang bagi guru untuk mempermudah proses belajar mengajar terutama dalam menanggapi situasi pandemi COVID-19 tahun 2020 yang melanda hampir semua negara di belahan dunia, termasuk Indonesia. Salah satu aspek yang terdampak pandemi Corona virus 2019 di tahun 2020 adalah pendidikan di seluruh dunia, yang mengarah kepada penutupan sekolah, madrasah, universitas, dan pondok pesantren (Setiawan, 2020). United Nations Educational, Scientific and Cultural Organization (UNESCO) (2020) menginformasikan bahwa hampir 92\% dari populasi siswa dunia mendapat imbas yang signifikan terkait penutupan akses besar-besaran di hampir 191 negara di dunia. Semenjak situasi tersebut, UNESCO menyarankan untuk menerapkan konsep pembelajaran jarak jauh dengan menggunakan sejumlah platform yang dapat diakses baik guru dan peserta didik di berbagai negara (Setiawan 2020). Selaras dengan perkembangan tersebut, Kementerian Pendidikan dan Kebudayaan (Kemendikbud) turut mengambil langkah konkrit dalam menanggapi situasi pandemi dengan memperkenalkan konsep belajar dari rumah (Kemendikbud, 2020). Hal ini tentunya menggerakkan semua pihak terkait terutama guru untuk meningkatkan kapasitas dirinya dalam menjalankan pembelajaran jarak jauh dengan cara menguasai teknologi dan produk teknologi yang dapat menciptakan pembelajaran secara daring. Hal ini juga menjadi tantangan bagi guru mata pelajaran matematika bagaimana agar materi matematika yang diajarkan melalui platform pembelajaran online tetap dipahami oleh peserta didik sehingga tercapai tujuan pembelajaran matematika itu sendiri.

Pada pengajaran matematika, teknologi dapat dimanfaatkan untuk materi aljabar, geometri, penghitungan, dan analisis data. Beberapa penelitian menunjukkan bahwa penggunaan teknologi dapat mendukung siswa dalam mempelajari prosedur matematika dan juga mengembangkan kemampuan matematis, seperti pemecahan masalah, penalaran, dan pembuktian (Gadanidis \& Geiger, 2010; Kastberg \& Leatham, 2005; Nelson, Christopher, \& Mims, 2009; Pierce \& Stacey, 2010; Roschelle et al., 2010; Suh \& Moyer, 2007). 
Konsep dan bukti yang mendasari matematika melibatkan ide-ide yang sulit dan abstrak bagi banyak siswa (Ekawati, 2016; Novitasari, 2016; Ruseffendi, 2006). Beberapa perangkat lunak (software) matematika yang dapat dimanfaatkan untuk membantu guru dan siswa dalam mengkonstruksi konsep-konsep matematika diantaranya adalah Cabri 3D, Wolfram Mathematica, GeoGebra, Maple, Matlab, dan Geometry Toolbox. Software tersebut dapat digunakan untuk membantu siswa memahami materi matematika dan memvisualisasikan konsep dan operasi dalam matematika. Beberapa penelitian mengungkapkan software matematika dapat meningkatkan pemahaman siswa tentang konsep dasar, teorema matematika, bahkan dapat menyelesaikan permasalahan matematika yang kompleks (Khouyibaba, 2010; Ochkov \& Bogomolova, 2015).

Pada bidang aljabar terdapat software Algebrator yang dapat memberikan langkah-langkah, solusi, dan penjelasan yang lengkap untuk soal matematika. Penggunaan software seperti ini dapat dimanfaatkan oleh guru untuk memberikan petunjuk dan saran pada diskusi kelompok siswa dalam menyelesaikan masalah matematika sehingga siswa mendapatkan pemahaman yang lebih baik (Umbara \& Rahmawati, 2018). Pada bidang geometri terdapat software Geometry Toolbox yang mengenalkan konsep dasar aljabar linier dan geometri. Penggunaan software geometri seperti Geometry Toolbox dapat membantu siswa mengkonstruksi dan melukis bangun geometri yang dirasa siswa abstrak, membuktikan konsep geometri Euclid sehingga konstruksi yang dibentuk akan lebih nyata dan akurat (Reflina, 2017). Beberapa aktivitas pembelajaran yang dapat menggunakan Geometry Toolbox diantaranya konsep dasar mengenai garis dan sudut, melukis poligon, konsep mengenai segitiga, simetri, dan transformasi.

Pada tahap penjajakan mitra kegiatan, guru-guru yang tergabung dalam Musyawarah Guru Mata Pelajaran (MGMP) Matematika SMA Kabupaten Bintan sebagai kelompok sasaran pengabdian masyarakat menyampaikan agar diadakan pelatihan pemanfaatan TIK dalam proses belajar mengajar. Hal itu berkaitan tidak hanya dengan tuntutan revolusi industri 4.0 dalam bidang pendidikan namun juga merespon tantangan pembelajaran jarak jauh pada masa pandemi COVID-19, dimana teknologi dimanfaatkan untuk menunjang pembelajaran matematika. Walaupun penggunaan software matematika diakui efektif, namun implementasinya di dalam kelas bukanlah tugas yang mudah bagi guru seperti yang dijelaskan Rowlett (2013) dan Weigand (2013). Situasi seperti ini menggerakkan dosen pendidikan matematika Fakultas Keguruan dan Ilmu Pendidikan Universitas Maritim Raja Ali Haji (UMRAH) untuk memperbaiki perwajahan pembelajaran. Salah satu kegiatan yang dilakukan adalah dengan menyelenggarakan Pengabdian Kepada Masyarakat (PKM). Dalam kegiatan ini, guru menjadi sasaran kegiatan agar mereka dapat memperbaiki praktek mengajar dalam kelas yang dapat berdampak pada proses pembelajaran.

Hasil penelusuran dari berbagai sumber ditemukan banyak penelitian yang telah mengembangkan media untuk pembelajaran jarak jauh (Alwan, 2018; Bali, 2019; Purnama, 2009; Septantiningtyas, 2018) namun hampir tidak ada penelitian maupun pengabdian yang mengangkat Geometry Toolbox sebagai software yang memiliki potensi dalam pembelajaran matematika. Hal inilah yang menggerakkan tim pengabdian untuk 
menjadi inisiator dalam mengangkat kebermanfaatan Geometry Toolbox dalam pembelajaran. Mengingat karakteristik pelajaran matematika, seperti objeknya yang abstrak, maka penggunaan software matematika Geometry Toolbox akan mendukung pembelajaran jarak jauh di masa pandemi COVID-19. Berdasarkan kondisi tersebut, kegiatan bertema "Peningkatan Penguasaan Teknologi dalam Menunjang Pembelajaran Matematika melalui Pelatihan Penggunaan Toolbox bagi MGMP SMA Kabupaten Bintan" penting untuk dilaksanakan.

\section{METODE PELAKSANAAN}

Kegiatan PKM ini dilaksanakan pada MGMP Matematika tingkat SMA se-Kabupaten Bintan dalam periode pelaksanaan Maret-Oktober 2020 dalam bentuk pelatihan online dengan puncak dari rangkaian PKM dilaksanakan pada tanggal 8 dan 9 Agustus 2020 . Metode yang digunakan dalam pengabdian masyarakat berbentuk rangkaian kegiatan berkesinambungan selama dua hari kerja secara daring berbantuan software Zoom Meetings. Berdasarkan analisis terhadap situasi yang terjadi, maka ditetapkan metode atau bentuk pelaksanaan kegiatan seperti yang diberikan dalam tabel berikut

Tabel 1. Metode pelaksanaan kegiatan

\begin{tabular}{|c|c|c|}
\hline No & Solusi Permasalahan & Metode Pelaksanaan \\
\hline 1 & $\begin{array}{l}\text { Pengarahan mengenai manfaat penggunaan teknologi dan } \\
\text { software matematika sebagai alat pembelajaran matematika }\end{array}$ & $\begin{array}{l}\text { - Pemaparan Materi dan } \\
\text { Diskusi } \\
\text { - Demonstrasi }\end{array}$ \\
\hline 2 & $\begin{array}{l}\text { Mendampingi guru-guru yang tergabung dalam MGMP } \\
\text { Matematika tingkat SMA di Kabupaten Bintan dalam } \\
\text { mengeksplorasi dan memanfaatkan Geometry Toolbox } \\
\text { dalam pembelajran matematika }\end{array}$ & $\begin{array}{l}\text { Hands on peserta } \\
\text { Pembimbingan intensif } \\
\text { Presentasi peserta }\end{array}$ \\
\hline 3 & $\begin{array}{l}\text { Melakukan evaluasi pelaksanaan kegiatan menggunakan } \\
\text { angket. }\end{array}$ & $\begin{array}{l}\text { Penyebaran angket kepada } \\
\text { peserta }\end{array}$ \\
\hline
\end{tabular}

Subjek kegiatan adalah guru Matematika dari 5 Sekolah Menengah Atas (SMA) Negeri yang tersebar di kabupaten Bintan diantaranya SMA Negeri 1 Bintan Timur, SMA Negeri 1 Toapaya, SMA Negeri 1 Teluk Bintan, SMA Negeri 1 Bintan Pesisir, dan SMA Negeri 1 Bintan Utara. Untuk dapat mengukur keberhasilan PKM digunakan empat aspek penentu keberhasilan kegiatan. Pertama, penilaian secara umum dari peserta mengenai kegiatan PKM. Dalam hal ini peserta menilai secara keseluruhan tentang pelaksanaan kegiatan. Kedua, pandangan mengenai relevansi dan signifikansi topik PKM yang dibawakan. Ketiga, kebermanfaaan yang dirasakan oleh peserta kegiatan. Keempat, ada tidaknya peningkatan pengetahuan, pemahaman, dan keterampilan dalam menggunakan teknologi dalam pembelajaran matematika.

Untuk dapat mengumpulkan informasi berupa respon peserta pada keempat aspek tersebut, digunakan instrumen angket online dengan platform Google Form yang disebarkan setelah agenda PKM berakhir sebagai bentuk evaluasi kegiatan oleh peserta. Selain itu, ada penyampaian kesan dan pesan peserta serta sesi tanya jawab di akhir kegiatan. Hasil karya guru dalam pelatihan berupa video pembelajaran berbasis Geometry 
Toolbox dengan bantuan software rekam desktop Bandicam dijadikan sumber untuk menganalisis keberhasilan PKM dalam memberikan pengetahuan, pemahaman, dan keterampilan. Karya tersebut telah serta diseminasikan menggunakan Youtube oleh peserta sehingga tim pengabdian menerima link address video tersebut. Selanjutnya data dianalisis secara deskriptif, kemudian disajikan dan disimpulkan untuk mendapatkan gambaran mengenai keberhasilan PKM.

\section{HASIL DAN PEMBAHASAN}

Kegiatan hari pertama diawali dengan pemberian materi "Peningkatan Penguasaan Teknologi dalam Menunjang Pembelajaran Matematika Melalui Pelatihan Penggunaan Toolbox Bagi MGMP SMA Kabupaten Bintan" oleh ketua PKM. Sasaran kegiatan pertama adalah peserta memahami hakikat integrasi teknologi dan sejumlah software yang dapat digunakan dalam pembelajaran matematika. Kemudian Geometry Toolbox diperkenalkan sebagai salah satu software yang dapat digunakan dalam pembelajaran. Gambar 1 berikut menunjukkan sesi pertama kegiatan PKM hari pertama.
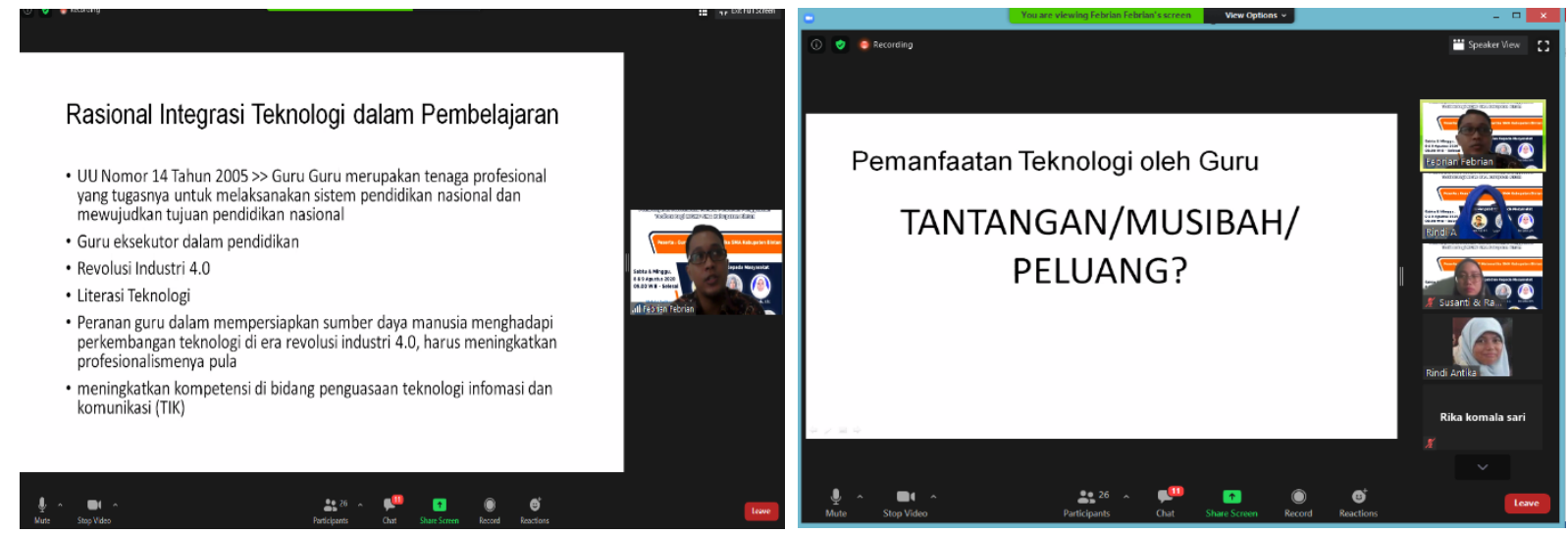

Gambar 1. Paparan materi integrasi teknologi dan pengenalan Geometry Toolbox

Di hari yang sama, kegiatan dilanjutkan dengan bimbingan unduh dan instalasi software Geometry Toolbox sebagai media mengajarkan geometri secara virtual (lihat Gambar 2). Pada sesi ini juga diperkenalkan Bandicam sebagai alat penangkap desktop yang berfungsi merekam tampilan layar laptop sehingga menghasilkan video. Sesi ini dibawakan oleh tim dari unsur mahasiswa. Sesi ini berjalan lancar dibuktikan dengan semua peserta dapat mengunduh dan menginstal software-software tersebut di masingmasing perangkat yang dimiliki peserta sehingga penggunaan Toolbox dapat diinisiasi pada kegiatan berikutnya. 


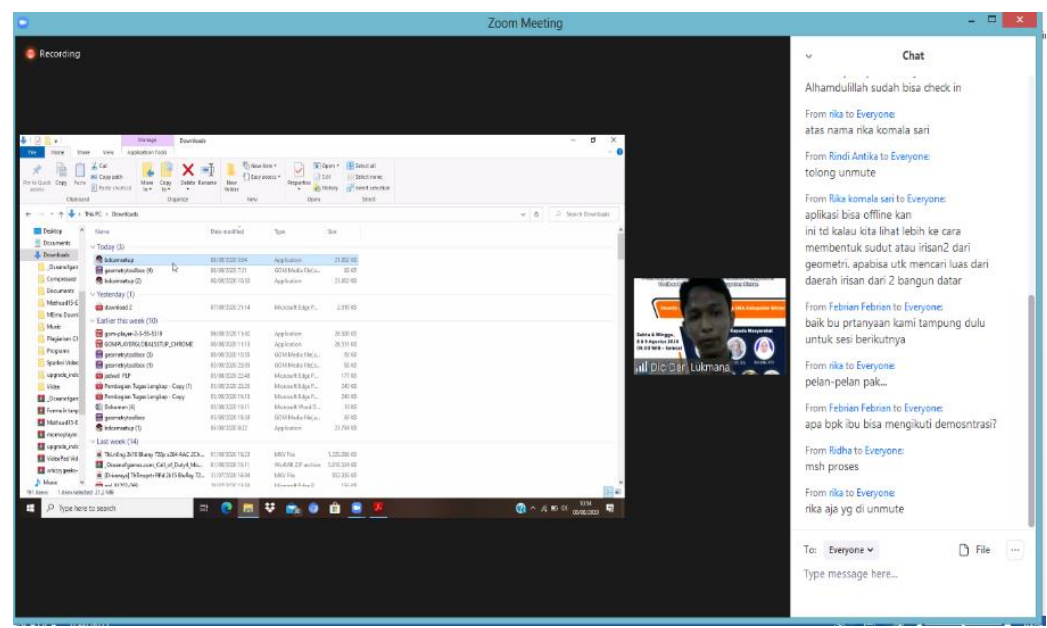

Gambar 2. Pendampingan instalasi dan unduh software

Kegiatan hari pertama diakhiri dengan sesi pengenalan Geometry Toolbox dari sisi fitur seperti alat tulis, busur, jangka, penggaris virtual serta bidang lukis. Sesi yang dibawakan oleh mahasiswa ini menekankan pada aspek fitur dasar yang diperlukan untuk dapat mengoperasikan Geometry Toolbox secara maksimal. Sejumlah peragaan secara daring menggunakan fitur screenshare pada menu Zoom Meetings dapat dimanfaatkan dengan baik sehingga semua peserta dapat memahami fitur Geometry Toolbox dengan baik. Gambar 3 menunjukkan demonstrasi penggunaan fitur Geometry Toolbox secara daring. Semua peserta dapat mengikuti pendampingan pengenalan dengan baik.

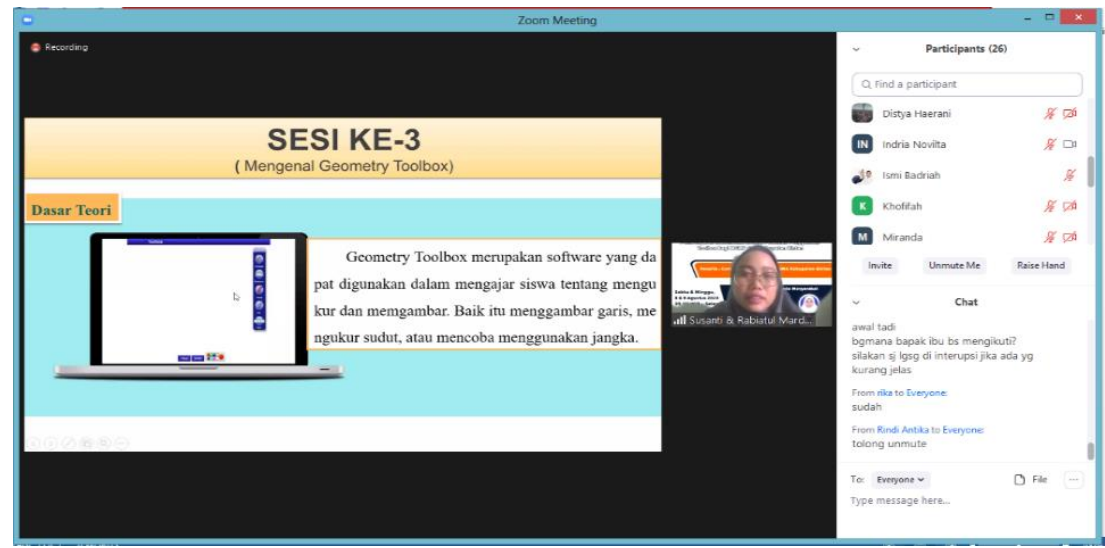

Gambar 3. Pendampingan pengenalan fitur dasar Geometry Toolbox

Setelah itu, kegiatan hari kedua menekankan pada contoh penggunaan Geometry Toolbox dengan bantuan Bandicam dan eksplorasi melalui hands on activity dimana semua peserta berlatih secara virtual dalam menggunakan Geometry Toolbox untuk menghasilkan video pembelajaran yang merupakan output kegiatan PKM ini. Hal ini selaras dengan rancangan pelaksanaan kegiatan yang disajikan pada tabel 1. Gambar 4 menunjukkan sesi kegiatan hari kedua. Dalam sesi tersebut dicontohkan beberapa penggunaan Geometry Toolbox untuk konstruksi sudut, lingkaran, perpotongan gari, lingkaran, dan lain sebagainya. Di hari kedua juga ditetapkan deadline penyerahan hasil karya peserta berupa video pembelajaran menggunakan Geometry Toolbox yang telah 
diunggah ke Youtube. Melalui tanya jawab dan pendampingan pada kegiatan hari kedua dapat dilihat adanya pemahaman peserta terhadap penggunaan software Geometry Toolbox.
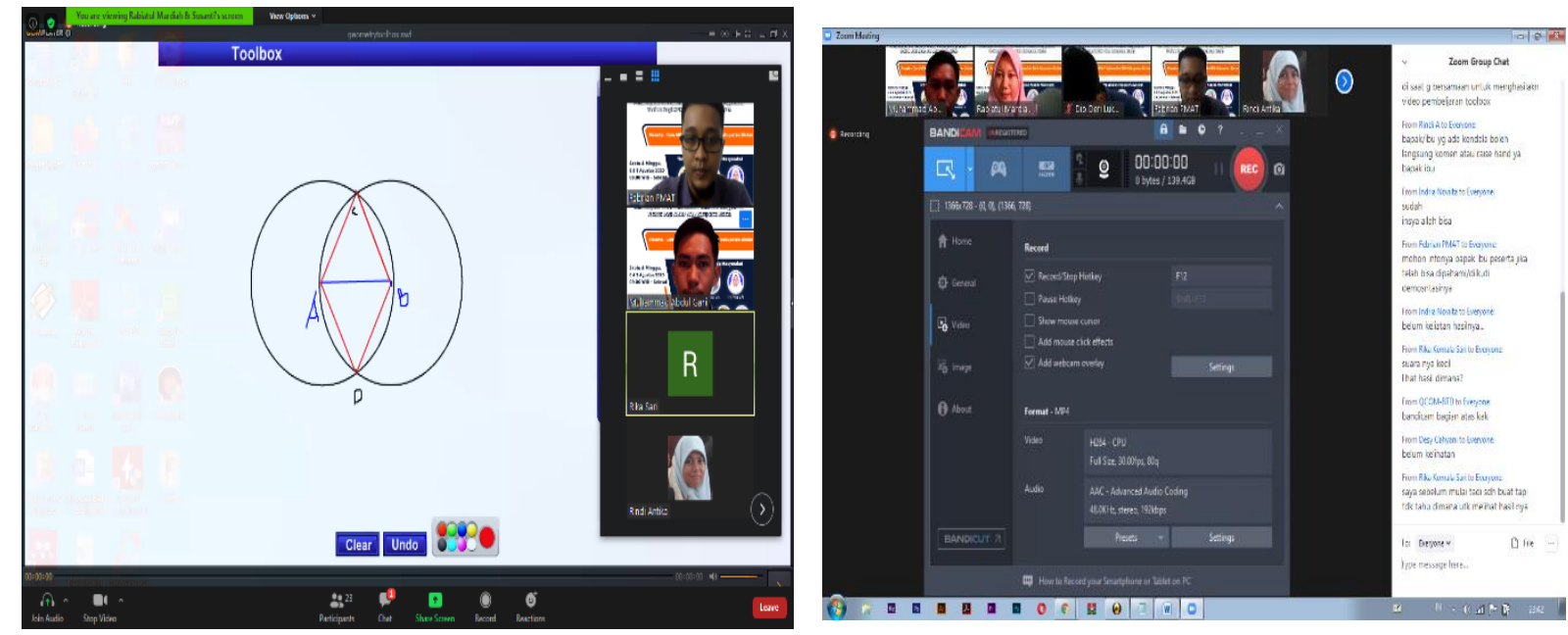

Gambar 4. Demonstrasi penggunaan Geometry Toolbox berbantuan Bandicam

Kegiatan hari kedua diakhiri dengan evaluasi kegiatan oleh peserta pelatihan. Perwakilan dari peserta menyampaikan pesan dan kesannya terhadap kegiatan PKM ini. Peserta menyampaikan bahwa kegiatan pelatihan online ini sangat bermanfaat bagi mereka karena memberikan pengetahuan dan pemahaman baru bagi mereka. Mereka menjadi tahu tentang software pembuat media pembelajaran sehingga berguna dalam situasi pandemi sekarang ini. Selanjutnya, peserta mengisi angket online dengan platform Google Form dengan butir pertanyaan berisi penilaian secara umum terhadap relevansi dan signifikansi topik PKM, kebermanfaatan, dan ada tidaknya peningkatan pengetahuan, pemahaman, dan keterampilan peserta. Secara umum, sebanyak 71\% peserta memberikan penilaian baik sekali terhadap pelaksanaan PKM pelatihan online dan 29\% memberikan penilaian baik. Aspek yang dinilai tersebut mencakup penguasaan materi oleh pemateri, cara menyampaikan materi, dan pengelolaan waktu setiap sesi. Diagram penilaian secara umum dapat dilihat dalam gambar di bawah ini. Pada aspek penilaian secara umum dapat disimpulkan bahwa kegiatan PKM berhasil dilaksanakan dengan baik.

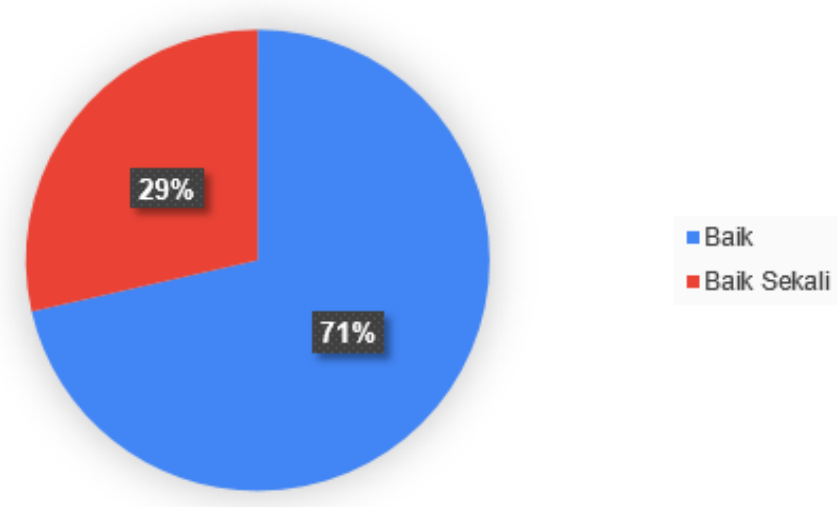

Gambar 5 Diagram penilaian secara umum tentang kegiatan pelatihan online 
Selanjutnya, berdasarkan angket yang disebarkan, 100\% peserta menyatakan bahwa pelatihan online Geometry Toolbox ini sangat relevan dan signifikan pengaruhnya bagi para peserta. Penilaian ini senada dengan pesan dan kesan yang disampaikan melalui tanya jawab di sesi evaluasi kegiatan dimana peserta menyampaikan bahwa di masa pandemi dan pembelajaran jarak jauh, kegiatan serupa inilah yang diperlukan para pendidik matematika guna dapat menambah variasi pembelajaran dengan memanfaatkan teknologi sehingga pembelajaran jarak jauh dapat berjalan dengan baik. Begitu juga dengan aspek kebermanfaatan, $100 \%$ peserta menilai pelatihan online telah memberikan manfaat yang besar bagi peserta. Diantara sejumlah manfaat yang diperoleh adalah adanya wawasan baru mengenai Geometry Toolbox sebagai software dalam pembelajaran matematika. Respon yang lebih umum menyatakan bahwa pelatihan tersebut dapat meningkatkan kretifitas guru dalam pembelajaran, menambah ilmu tentang software yang dapat dijadikan referensi dalam pembelajaran serta mendapatkan wawasan baru tentang trik menghasilkan video pembelajaran.

Aspek terakhir yang dinilai adalah ada atau tidaknya peningkatan pengetahuan, pemahaman, maupun keterampilan setelah mengikuti kegiatan pelatihan. Hasil penelusuran didapatkan $100 \%$ peserta menyatakan terjadi peningkatan pengetahuan mengenai software pembelajaran matematika terutama Geometry Toolbox dan lainnya; peningkatan pemahaman tentang integrasi teknologi daam pembelajaran matematika; serta keterampilan dalam mengoperasikan software yang dipelajari untuk menghasilkan video pembelajaran.

Aspek peningkatan yang terjadi ini terbukti lewat ouput kegiatan pelatihan berupa video pembelajaran berbasis Geometry Toolbox yang diunggah peserta melalui Channel Youtube. Melalui tagihan ini, dapat dinilai ada tidaknya peningkatan pemahaman dan keterampilan peserta terhadap penggunaan software. Sebanyak 100\% peserta berhasil membuat video pembelajaran yang diunggah ke Channel Youtube peserta. Pada video tersebut, Geometry Toolbox digunakan oleh peserta dalam mengajarkan sejumlah topik matematika seperti lingkaran luar dan dalam segitiga, persamaan lingkaran, dan konstruksi sudut. Gambar 6 menunjukan video pembelajaran salah satu peserta yang diunggah ke Channel Youtube. Dapat disimpulkan terjadi peningkatan pengetahuan, pemahaman, dan keterampilan penggunaan software di kalangan peserta. Dengan demikian, aspek terakhir ini dipandang berhasil. 


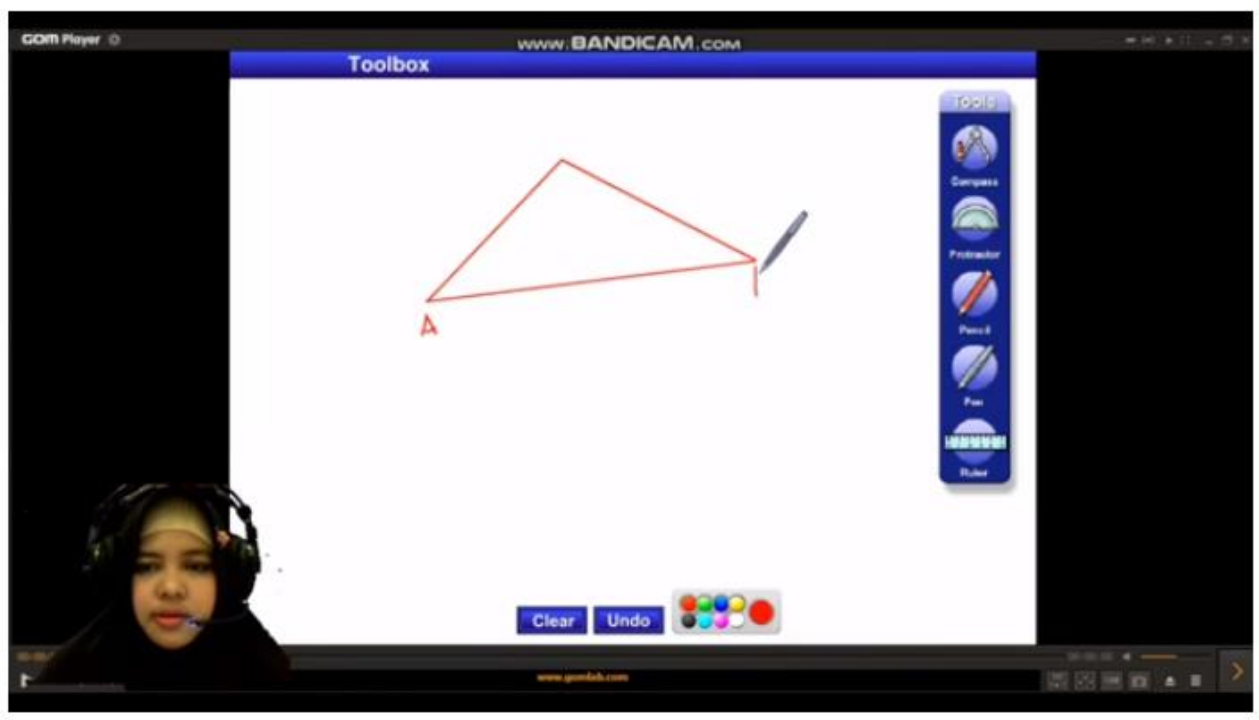

Gambar 6. salah satu hasil pelatihan online dari peserta yang dapat diakses di https://youtu.be/411 Wi7coUQ

Berdasarkan hasil analisis terhadap empat aspek sebagai indikator keberhasilan kegiatan, maka dapat disimpulkan bahwa pelatihan online bertemakan penggunaan Geometry Toolbox untuk mendukung pembelajaran jarak jauh telah berhasil mencapai tujuan PKM yang ditetapkan. Hasil akhir berdasarkan ouput pelatihan, semua peserta memiliki pengetahuan, pemahaman terkait Geometry Toolbox sebagai software pembelajaran matematika serta memiliki keterampilan yang memadai dalam menggunakannya. Setidaknya melalui kegiatan ini guru berhasil melakukan adaptasi terhadap perkembangan teknologi dan menggunakannya untuk proses pembelajaran. Tentunya ini merupakan hal positif mengingat guru dalam bidang pembelajarannya harus mampu beradaptasi terhadap perkembangan teknologi dan mampu memanfaatkannya (Astuti \& Febrian 2019).

Dengan penguasaan teknologi yang diperoleh guru melalui pelatihan ini, maka pembelajaran jarak jauh tidak sulit untuk diterapkan. Guru telah memiliki bekal dalam menjalankan pembelajaran jarak jauh yaitu kemampuan membuat bahan ajar yang relevan dengan konsep belajar dari rumah menggunakan teknologi yang sesuai, dalam hal ini Geometry Toolbox untuk mengajarkan sejumlah topik matematika. Dengan demikian, melalui pelatihan ini guru dapat melaksanakan program belajar dari rumah yang dianjurkan Kemendikbud dalam merespon situasi pandemi COVID 2019 yang telah berdampak kepada pendidikan di Indonesia (Kemdikbud, 2020).

\section{SIMPULAN}

Pelaksanaan agenda PKM dalam bentuk pelatihan online penggunaan Geometry Toolbox telah berhasil dan tercapai output kegiatan dalam bentuk hasil karya peserta berupa video pembelajaran yang telah di upload di youtube. Pelaksanaan kegiatan dapat disimpulkan berhasil berdasarkan analisis terhadap empat aspek yang dijadikan indikator keberhasilan. Semua peserta telah memiliki pengetahuan dan pemahaman 
dalam mengintegrasikan teknologi pada pembelajaran matematika serta telah mengetahui dan memahami Geometry Toolbox sebagai salah satu contoh produk teknologi yang dapat dimanfaatkan dalam pembelajaran matematika. Melalui kegiatan pelatihan ini, peserta memiliki keterampilan memadai dalam menggunakan dan mengkreasikan bahan ajar berbasis Geometry Toolbox dalam wujud video pembelajaran pada sejumlah topik matematika. Dengan demikian, kemampuan baru yang diperoleh dari pelatihan ini dapat mendukung pembelajaran jarak jauh di masa pandemi COVID-19.

\section{UCAPAN TERIMA KASIH}

Ucapan terima kasih kepada Universitas Maritim Raja Ali Haji (UMRAH) atas pendanaan penuh kegiatan melalui skema Pengabdian kepada Masyarakat (PkM) yang dikelola oleh LP3M UMRAH. Ucapan terimakasih juga diberikan kepada mahasiswa kami Santi, Rabiatul Mardiah, Dio Deri Lukmana, dan Muhammad Abdul Gani yang terlibat penuh mensukseskan agenda PKM.

\section{DAFTAR RUJUKAN}

Alwan, M. (2018). Pengembangan multimedia e-book 3D berbasis mobile learning untuk mata pelajaran geografi SMA guna mendukung pembelajaran jarak jauh. At-Tadbir, 1(2), 26-40.

Astuti, P., \& Febrian, F. (2019). Diseminasi online multimedia pembelajaran matematika yang dikembangkan menggunakan videoscribe. Jurnal Anugerah, 1(1), 19-24. https://doi.org/10.31629/anugerah.v1i1.1650

Bali, M. M. E. I. (2019). Implementasi media pembelajaran berbasis teknologi informasi dan komunikasi dalam distance learning. Tarbiyatuna: Kajian Pendidikan Islam, 3(1), 29-40.

Ekawati, A. (2016). Penggunaan software geogebra dan microsoft mathematic dalam pembelaran matematika. Math Didactic: Jurnal Pendidikan Matematika, 2(3), 148153. https://doi.org/10.33654/math.v2i3.43

Gadanidis, G., \& Geiger, V. (2010). A social perspective on technology-enhanced mathematical learning: from collaboration to performance. ZDM, 42(1), 91-104.

Kastberg, S., \& Leatham, K. (2005). Research on graphing calculators at the secondary level: implications for mathematics teacher education. Contemporary Issues in Technology and Teacher Education, 5(1), 25-37.

Kemdikbud. (2019).Kemdikbud luncurkan program digitalisasi sekolah. Retrieved from https://www.kemdikbud.go.id/main/blog/2019/09/kemendikbud-luncurkanprogram-digitalisasi-sekolah

Kominfo. (2019. Digitalisasi sekolah percepat perluasan akses pendidikan berkualitas di daerah 3T. Retrieved from https://kominfo.go.id/index.php/content/detail/22211/ digitalisasi-sekolahpercepat-perluasan-akses-pendidikan-berkualitas-di-daerah-3t/0/artikel_gpr 
Khouyibaba, S. (2010). Teaching mathematics with technology. Procedia - Social and Behavioral Sciences, 9, 638-643. https://doi.org/10.1016/j.sbspro.2010.12.210

Nelson, J., Christopher, A., \& Mims, C. (2009). TPACK and web 2.0: Transformation of teaching and learning. Tech Trends, 53(5), 80-85.

Novitasari, D. (2016). Pengaruh penggunaan multimedia interaktif terhadap kemampuan pemahaman konsep matematis siswa. FIBONACCI: Jurnal Pendidikan Matematika Dan Matematika, 2(2), 8. https://doi.org/10.24853/fbc.2.2.8-18

Ochkov, V., \& Bogomolova, E. (2015). Teaching mathematics with mathematical software. Journal of Humanistic Mathematics, 5(1), 265-285. https://doi.org/10.5642/ jhummath.201501.15

Pierce, R., \& Stacey, K. (2010). Mapping pedagogical opportunities provided by mathematics analysis software. International Journal of Computers for Mathematical Learning, 15(1), 1-20. https://doi.org/10.1007/s10758-010-9158-6

Purnama, B. E. (2009). Pemanfaatan teknologi WAP telepon seluler untuk media pembelajaran jarak jauh, 1(3), 22-28.

Reflina. (2017). Pemanfaatan software Cabri Geometry II dalam pembelajaran geometri. Ijtimaiyah Jurnal Pendidikan Ilmu Sosial Budaya, 1(2).

Roschelle, J., Shechtman, N., Tatar, D., Hegedus, S., Hopkins, B., Empson, S., Gallagher, L. P. (2010). Integration of technology, curriculum, and professional development for advancing middle school mathematics: Three large-scale studies. American Educational Research Journal, 47(4), 833-878. https://doi.org/10.3102/0002831210367426

Rowlett, P. J. (2013). Developing a healthy scepticism about technology in mathematics teaching. Journal of Humanistic Mathematics, 3(1), 136-149. https://doi.org/10.5642/ jhummath.201301.11

Ruseffendi, H. E. . (2006). Pengantar kepada membantu guru mengembangkan kompetensinya dalam pengajaran matematika untuk meningkatkan CBSA. Bandung: Tarsito.

Septantiningtyas, N. (2018). Pengaruh pembelajaran jarak jauh dengan aplikasi google class terhadap hasil belajar mahasiswa. Edureligia; Jurnal Pendidikan Agama Islam, 2(2), 131-135. https://doi.org/10.33650/edureligia.v2i2.714

Setiawan, A. R. (2020). Lembar kegiatan literasi saintifik untuk pembelajaran jarak jauh topik penyakit coronavirus 2019 (COVID-19). Edukatif: Jurnal Ilmu Pendidikan, 2(1), 28-37. https://doi.org/10.31004/edukatif.v2i1.80

Suh, J., \& Moyer, P. S. (2007). Developing students' representational fluency using virtual and physical algebra balances. Journal of Computers in Mathematics and Science Teaching, 26, $155 . \quad$ Retrieved from http://www.editlib.org/index.cfm?fuseaction=Reader.

ViewFullText\&paper_id=22799 
Umbara, U., \& Rahmawati, I. (2018). Pembelajaran matematika berbantuan software algebrator untuk meningkatkan kemampuan pemahaman matematis siswa. Jurnal Elemen, 4(1), 9. https://doi.org/10.29408/jel.v4i1.508

Weigand, H. (2013). Looking back and ahead-didactical implications for the use of digital technologies in the next decade. Teaching Mathematics and Its Applications, 33(1). 